Onder redactie van:

Prof. mr. dr. B.M.E.M. Schols

Prof. mr. dr. W. Burgerhart

Prof. mr. dr. F.W.J.M. Schols

Mr. F.M.H. Hoens

Mr. G.A. Tuinstra

Mr. J.Th.M. Diks

Mr. M.J.P. Schipper

Mr. dr. N.V.C.E. Bauduin

Mr. E.C.E. Schnackers

Mr. dr. J.W.A. Rheinfeld

\title{
Advotip
}

Erfrecht voor de advocaat

\section{Risicoaansprakelijkheid met een erfrechtelijk sausje op hoogte}

Soms loop je een uitspraak tegen het lijf waar zoveel 'leuks' in zit, dat het bijna te veel is. Zo ook bij de uitspraak die ik vandaag in deze AdvoTip bespreek. Het betreft een uitspraak van 6 december 2017 van de Rechtbank Oost-Brabant (ECLI:NL:RBOBR:2017:6446). De zaak leent zich voor een bespreking van erfrechtelijke vraagstukken als de saisine, het (zuiver/beneficiair) aanvaarden van een nalatenschap en wordt gecompleteerd door een creatieve rechter. Buiten het te bespreken (erfrechtelijk) kader van de AdvoTip zou een liefhebber zijn hart ook nog kunnen ophalen bij een mooi voorbeeldje 'eigen schuld bij risicoaansprakelijkheid'. Kortom, smullen.

$\mathrm{Na}$ een overlijden is de saisine als het ware het begin van alles. De saisine is een van de kernwaarden en kernbeginselen van ons erfrecht. Eenieder die met het erfrechtelijk bijltje hakt, zal dit beamen. Niet voor niets hoort de regel dat de erfgenamen in beginsel de positie van de erflater 'voortzetten', tot de eerste lessen van iedere (basis)cursus erfrecht. In artikel 4:182 BW staat het wettelijke kader:

'1. Met het overlijden van de erflater volgen zijn erfgenamen van rechtswege op in zijn voor overgang vatbare rechten en in zijn bezit en houderschap. De eerste zin geldt niet wanneer de nalatenschap ingevolge artikel 13 wordt verdeeld; in dat geval volgt de echtgenoot van rechtswege op in het bezit en houderschap van de erflater.

2. Zij worden van rechtswege schuldenaar van de schulden van de erflater die niet met zijn dood tenietgaan. Is een prestatie deelbaar, dan is ieder van hen verbonden voor een deel, evenredig aan zijn erfdeel, tenzij zij hoofdelijk zijn verbonden.' (Curs. FH)

Als we deze tekst wat nader bekijken, komen enige vragen op. Enkele daarvan bespreek ik kort.

Vanzelfsprekend werkt de saisine alleen voor zover sprake is van 'voor overgang vatbare rechten'. Want wat zouden we anders aan moeten met een recht dat niet overdraagbaar is? Verstappen (Handboek Erfrecht, nr. XIII.2) meldt dat veel nietvermogensrechtelijke rechten en bevoegdheden in beginsel eindigen bij overlijden van de rechtsdrager en dus niet overgaan. Ook noemt hij het recht van vruchtgebruik. De duur waarvoor dit kan worden gevestigd, (zie artikel 3:203 lid 2 BW) kan niet langer zijn 
dan het leven van de vruchtgebruiker. Uiteraard gaat dit niet op als het vruchtgebruik is gevestigd ten behoeve van twee of meer personen. Een (eerste) overlijden betekent dan niet ook het einde van het recht van de andere vruchtgebruikers.

Hoe zit het ook weer bij het tweede lid van artikel 4:182 BW: de schulden-kant van de saisine? Een erfgenaam wordt van rechtswege schuldenaar van de schulden van de overledene voor zover die niet door de dood tenietgaan. Denk bij dit tenietgaan aan de verplichtingen van de overledene uit bijvoorbeeld een arbeidsovereenkomst of een opdracht aan een kunstenaar.

Of aan de (wettelijke) verplichtingen tot het voldoen van levensonderhoud (alimentatie), waarbij een contractueel beding dat de alimentaire verplichting wél overgaat op de erven, is toegestaan. Artikel 4:182 lid 2 BW geldt enkel voor de schulden van de erflater zelf. Dit zijn de schulden van artikel 4:7 lid 1 aanhef en onder a BW. En dat zijn dus niet alle 'andere' schulden van de nalatenschap van datzelfde artikel. En dat is weer goed om te weten als we voor de uitwinning artikel 4:184 BW erbij pakken:

'1. Schuldeisers van de nalatenschap kunnen hun vorderingen op de goederen der nalatenschap verhalen.

2. Een erfgenaam is niet verplicht een schuld der nalatenschap ten laste van zijn overig vermogen te voldoen, tenzij hij:

a. zuiver aanvaardt, behalve voor zover de schuld niet op hem rust of hij deze geheel of gedeeltelijk niet hoeft te voldoen ingevolge artikel 194a lid 2 en onverminderd de artikelen 14 lid 3 en 87 lid 5; [...].'

Schuldeisers van de nalatenschap, en dat is de 'grote club' van alle schuldeisers genoemd in artikel 4:7 lid $1 \mathrm{BW}$, kunnen verhaal halen op de goederen van de nalatenschap. En hoewel een erfgenaam van rechtswege schuldenaar wordt van de (letter a) schulden van de overledene, zien we desalniettemin in artikel 4:182 lid 2 aanhef en onder a BW dat als die erfgenaam zuiver aanvaardt, hij niet alleen die (letter a) schulden van de overledene - maar in principe ook de andere schulden van de nalatenschap (artikel 7 lid 1 aanhef en onder b tot en met i BW) - ten laste van zijn eigen vermogen moet voldoen. De nalatenschapsschuldeiser is er blij mee, de zuiver aanvaardende erfgenaam minder. Het veiligste advies is en blijft dan ook om 'altijd' beneficiair te aanvaarden.

En daarmee belanden we bij de vragen over de combinatie van de wettelijke verdeling en de saisine. Als de wettelijke verdeling van artikel 4:13 e.v. BW van kracht is, werkt de saisine iets (anders) voor de activa-kant van de nalatenschap. Dit blijkt uit de tweede volzin van het eerste lid van artikel 4:182 BW. Niet de 'erfgenamen', maar de niet van tafel en bed gescheiden langstlevende echtgenoot van de overledene volgt van rechtswege en 'alleen' op in 'bezit en houderschap'. En hoewel logisch en praktisch (anders zou de wettelijke verdeling een daadwerkelijke verdeling zijn, en dat is het nu niet), maakt dit wel nieuwsgierig naar de manier waarop de wetgever dan met de passiva-zijde omgaat.

Voor de hand ligt immers dat ook bij de schulden-kant voor een 'afwijkend regime' zou zijn gekozen. En dan wordt het raar. Nergens in titel 6 Boek 4 BW staat een regeling waardoor, als de wettelijke verdeling van kracht is, de kinderen niet van rechtswege (mede)schuldenaar zijn geworden van de schulden van de erflater die niet met zijn dood tenietgaan. Kortom, de kinderen krijgen als de wettelijke verdeling van kracht is geen goederen, maar 'slechts' een niet-opeisbare geldvordering op de langstlevende, en toch zijn zij desalniettemin medeaansprakelijk voor de schulden van de overledene. Het lijkt 
erop alsof zij wel ook verhaalsaansprakelijk zijn (na zuivere aanvaarding) met het eigen vermogen voor de schulden van de nalatenschap, ondanks dat ze vooralsnog niets 'ontvangen' waaruit of waarmee ze die schulden kunnen voldoen. Gelukkig voor de kinderen is er toch niet echt sprake van een spel met alleen maar 'nieten'. De 'oplossing' staat in artikel 4:14 BW. Het eerste lid verplicht de langstlevende tot voldoening van de bedoelde schulden. Per saldo is dit een uitbreiding van diens aansprakelijkheid.

Relevant voor de kinderen-erfgenamen is artikel 4:14 lid 3 BW:

'Voor schulden van de nalatenschap kunnen de goederen van een kind niet worden uitgewonnen, met uitzondering van de in artikel 13 lid 3 bedoelde geldvordering. Uitwinning van die goederen is wel mogelijk voor zover de geldvordering van het kind is verminderd door betaling of door overdracht van goederen, tenzij het kind goederen van de echtgenoot aanwijst die voldoende verhaal bieden.' (Curs. FH)

Ook als de wettelijke verdeling van kracht is, zijn zij aansprakelijk voor de schulden van de erflater, maar er is vooralsnog geen uitwinning mogelijk van hun eigen/privévermogen.

Genoeg 'saisine-theorie'. Laten we de feiten bekijken van de casus van de Rechtbank Oost-Brabant. Dochter $X$ is aan het werk op het dak van haar (oude) vader. Tijdens de werkzaamheden valt zij van het dak en loopt daarbij ernstig letsel op. Anderhalve week na de val stelt dochter $X$ haar vader aansprakelijk voor het ongeval en de door haar geleden schade. De door vader ingeschakelde verzekeraar wijst - namens vader - de aansprakelijkheid van de hand. De aansprakelijkstelling van haar vader door dochter $\mathrm{X}$ is gebaseerd op artikel 6:174 lid1 BW. Zoals u weet, vestigt dit artikel een risicoaansprakelijkheid voor de bezitter van een opstal. Anders dan de titel van deze AdvoTip misschien doet vermoeden, is het niet de 'vallende' dochter X, maar de vader die enige tijd na de afwijzing van zijn aansprakelijkheid overlijdt. De erfgenamen van vader zijn dochter $X$ en haar twee zussen $Y$ en $Z$. Dochter $X$ laat de aansprakelijkheidskwestie niet rusten en start een procedure tegen haar zussen $\mathrm{Y}$ en $\mathrm{Z}$.

De rechtbank gaat bij de beoordeling van de zaak eerst en vooral in op de vraag of dochter A geen eigen schuld heeft voor de geleden schade. Immers, naar mate er meer 'eigen schuld' is bij dochter $\mathrm{X}$ neemt de risicoaansprakelijkheid bij de vader af. De overwegingen van de rechtbank geven een mooi inkijkje in de elementen die daarbij een rol kunnen spelen. Dochter $X$ wist dat het dak al 20 jaar niet was vervangen, dat er verschillende lekkages waren geweest, dat lekkages tot het rot worden van een houten dakconstructie kunnen leiden en dus had zij er rekening mee moeten houden dat het dak in slechte staat zou zijn. Dochter X heeft, zo de rechtbank, risico's genomen en onvoorzichtig gehandeld. Op grond daarvan concludeert de rechtbank dat zestig procent van de schade van dochter $X$ voor haar eigen rekening dient te blijven. De vergoedingsplicht op grond van de risicoaansprakelijkheid van vader als bezitter van de opstal (krachtens artikel 6:174 BW) bedraagt 'slechts' veertig procent van de totale schade.

Daarmee belanden we bij de erfrechtelijke kant van de kwestie. Als vader voor veertig procent van de schade aansprakelijk was, dan geldt dat dankzij de saisine ook voor zijn erfgenamen. Dochter X spreekt immers haar zussen $X$ en $Y$ aan in hun hoedanigheid van mede-erfgenamen van vader. De zussen ontkennen niet dat zij als mede-erfgenaam aansprakelijk zijn voor de schulden van hun vader. Wel voeren zij in dit verband aan dat 
ook dochter $\mathrm{X}$ zelf als mede-erfgenaam (mede)aansprakelijk is voor de schulden van haar vader en dat van hoofdelijke aansprakelijkheid hier geen sprake is.

We herkennen de essentie van de saisine in al zijn 'schoonheid'. Erfgenamen $Y$ en $Z$ zijn 'uiteraard' aansprakelijk voor de schulden van hun vader, maar als zij dat zijn, is erfgename $X$ het ook. En via artikel 4:182 lid 2 slot BW weten we dat bij deelbare prestaties (zoals de onderhavige schade van dochter $A$ ) de erfgenamen ieder voor een deel zijn verbonden dat gelijk is aan hun erfdeel. In onze casus en uitgaand van drie erfgenamen met gelijke erfdelen, moet dochter A dus ook nog eens een derde van de veertig procent voor eigen rekening 'nemen'.

Dochter $X$ gaat niet inhoudelijk in op de stellingen van haar zussen. Wel geeft $X$ aan dat zij ervan uitgaat dat als aansprakelijkheid van vader vaststaat, de aansprakelijkheidsverzekeraar van vader een schade-uitkering zal doen waaruit haar vordering zal kunnen worden voldaan. En dan volgt een even eigenaardige als merkwaardige wending. Raadplegen we de overwegingen van de rechtbank:

'3.24. [Dochter X] vraagt de rechtbank voor recht te verklaren dat haar twee zussen, [...] , aansprakelijk zijn voor haar schade. [Dochter X] spreekt [de zussen] aan als erfgenamen van haar vader, waarbij onduidelijk is in hoeverre zij hen buiten de boedel om - met hun eigen vermogen aansprakelijk acht.' (Curs. FH)

Lezen we het goed, en stelt de rechtbank hier dat dochter $X$ de zussen $Y$ en $Z$ weliswaar aansprakelijk houdt en stelt, maar de zussen kennelijk ondanks 'erfgenaamaansprakelijkheid', niet privé-aansprakelijk stelt of acht?

Dat zulks in ieder geval voor de verhaalskant van de zaak alleen het geval is indien de zussen beneficiair aanvaard hebben, hoeft voor een erfrechtpracticus geen verdere toelichting. Maar hoe ziet de rechtbank een en ander:

'[...] [Dochter X] heeft geen feiten of omstandigheden gesteld die de conclusie rechtvaardigen dat [de zussen] met hun eigen vermogen aansprakelijk zijn voor de schuld van hun vader jegens [Dochter X]. Het is de rechtbank onder meer niet bekend of [de zussen] (en [Dochter X]) de nalatenschap zuiver of beneficiair hebben aanvaard en of de boedel toereikend is om daaruit de vordering van [Dochter X] te voldoen. Gelet op de mededeling van [Dochter X] ter zitting dat zij aanneemt dat de aansprakelijkheidsverzekeraar zal uitkeren als de aansprakelijkheid van haar vader als opstalbezitter komt vast te staan, begrijpt de rechtbank dat [Dochter $\mathrm{X}$ ] met deze procedure eerst en vooral een beslissing wenst te verkrijgen over de aansprakelijkheid van haar vader en haar daarmee verband houdende vordering op de boedel. De rechtbank zal haar vordering daarom ook zo opvatten en - rekening houdend met het eigen schuld percentage van $60 \%$ - voor recht verklaren dat de vader van [Dochter $\mathrm{X}$ ] als opstalbezitter aansprakelijk was voor $40 \%$ van de schade die [Dochter $\mathrm{X}$ ] lijdt als gevolg van het ongeval [...] en dat [Dochter $X]$ in verband daarmee een vordering heeft op de boedel.' (Curs. FH)

De rechtbank stelt dat zij een verklaring voor recht kan afgegeven waaruit blijkt dat niet de erfgenamen maar slechts de boedel voor veertig procent (verhaals)aansprakelijk is. Erfrechtelijk bezien is hier nog wel wat op aan te merken. Want na zuivere aanvaarding is, als bekend, verhaal mogelijk (door de schuldeisers van de nalatenschap) op zowel de nalatenschapsgoederen als de privé-/eigen goederen van de erfgenamen. En na een beneficiaire aanvaarding blijft de aansprakelijkheid van de erfgenamen uit hoofde van de 
saisine ongewijzigd, maar veranderen wel de verhaalsmogelijkheden van de schuldeisers van de nalatenschap. Er is dan door die schuldeisers geen verhaal meer mogelijk op de privé-/eigen goederen van de beneficiair aanvaard hebbende erfgenaam. Het heeft er alle schijn van dat de rechtbank voorbij lijkt te gaan aan deze erfrechtelijke kant van de zaak. Naar het zich laat aanzien, heeft de rechtbank daarbij de familieverhoudingen voor ogen. Deze zouden (wellicht) onder druk (kunnen) komen te staan als verhaal op de privé (eigen) vermogens van de zussen mogelijk zou zijn. De rechtbank wekt in ieder geval de indruk dit niet/minder wenselijk te vinden. Dat is mooi en sympathiek en wellicht naar de idee van menigeen ook wel rechtvaardig, maar of een en ander ook in overeenstemming is met het recht, is een andere kwestie. De legisten onder $u$ hebben waarschijnlijk wat moeite met de uitspraak. En zij die menen dat recht vooral rechtvaardig dient te zijn, en dat rechters geen 'letterknechten' moeten zijn, zien dat waarschijnlijk weer anders.

Desalniettemin is ook deze uitspraak weer een mooi voorbeeld van de 'saisine in de praktijk' en een fraai bewijs van het belang van beneficiaire aanvaarding. Niet iedereen zal op een begripvolle rechter kunnen rekenen, zoals in de onderhavige zaak.

Tot de volgende keer!

mr. F.M.H. Hoens

Radboud Universiteit Nijmegen

Adviseur en estate planner te Nijmegen

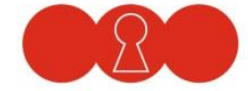

ScholsBurgerhartSchols

www.scholsburgerhartschols.nl

\section{Boomjuridisch}

\author{
Postbus 85576 \\ 2508 CG Den Haag \\ $\mathrm{T}(070) 3307033$ \\ E info@boomjuridisch.nl \\ I www.boomjuridisch.nl
}

